\title{
Evaluating Chemistry Teachers Within the Context of Teacher Characteristics
}

\author{
Mehmet Yüksel \\ Correspondence: Mehmet Yüksel, Gazi University, TUSAŞ Kazan Vocational School, Aydın Mahallesi Aydın Küme \\ Evleri, 1. Cadde 79/A, 06980 Kahramankazan/Ankara, Turkey.
}

Received: August 11, 2019

doi:10.11114/jets.v7i11.4441

\author{
Accepted: August 28, $2019 \quad$ Online Published: August 29, 2019
}

URL: https://doi.org/10.11114/jets.v7i11.4441

\begin{abstract}
There are several characteristics arising from the role that education and training activities impose on teachers. That teachers have different characteristics stems from the fact that the teaching role has a multi-dimensional behavior pattern. Therefore, teacher characteristics are being researched in various fields of science and various subjects. One of these domains is about the characteristics of chemistry teachers. Teacher characteristics are decisive for both effective education and educational improvement. Therefore, it is important to analyze the characteristics of chemistry teachers within a systematic approach. The aim of this study is to try to propose a multi-criteria model for the analysis of characteristics of chemistry teachers and their evaluation in the context of teacher characteristics. With the multi-criteria decision-making model proposed in the study, a 9th grade chemistry teacher was evaluated in detail and holistically. The proposed model allowed the evaluation of teacher characteristics on the basis of cognitive, affective and psychomotor dimensions. In this study, the level of the roles of each of teacher characteristics in evaluating the effectiveness of chemistry education was also determined. Furthermore, the competence level of the chemistry teacher in this study was determined based on each characteristic.
\end{abstract}

Keywords: characteristics of teachers, high school 9th grade chemistry course, TOPSIS, AHP

\section{Introduction}

The phenomenon of education is one of the main tools that people use to survive on the planet and overcome the difficulties they face. Education also enables the achievement or realization of the aims with the learning phenomenon that is unique to human. Depending on the learning capacity and ability of human beings, the search for understanding the universe, nature, living things and the society in which they live in, the historical process continued uninterruptedly with the educational activity. Throughout the historical process, the search of human beings in the scientific context has found existence in the field of philosophy until the last three centuries (Coşkun, 2016; Özlem, 1994; Yavuz, 2008). However, as a result of the accumulation of knowledge created by mankind in thousands of years before the last three centuries, and as a result of the increasing accumulation of knowledge in the last three hundred years, human beings have tried to realize their aims with different fields of science. One of these major domains is defined as chemistry.

Through chemistry education given at different academic levels, it is possible to transfer the knowledge about the field of chemistry to the next generations, solve the problems with the current knowledge, and also acquire the knowledge required for the solution of the problems of chemistry. However, as in other fields of science, there are differences or difficulties in the phenomenon of chemistry education stemming from the nature of chemistry (Mete, 2018; Tsaparlis, 2015). Therefore, theoretical and practical studies are carried out to improve the effectiveness of chemistry education. In the literature review, various studies (Batı, 2018; Çalık, Ayas and Ünal, 2006; Ulutaş, Üner, Turan Oluk, Yalçın Çelik and Akkuş, 2015) were conducted in different contexts to improve the effectiveness of chemistry education. One of them is the characteristics of chemistry teachers. In the literature, few studies (Childs, 2009) focused on the characteristics of chemistry teachers while teacher characteristics were subject to study within different contexts in other fields (Arsal, 2004; Özkan ve Arslantaş, 2013; Yetişir, 2014). The main reason for investigating teacher characteristics in various fields of science and in different subjects stems from the fact that the teaching role has a multi-dimensional behavior pattern. This multi-dimensionality arises from the relationship of teachers with various segments such as students, friends who are teachers, administrators, society, school, family as part of their roles and the nature of the phenomenon which is called learning. 
As can be seen from the literature findings above, it is important to analyze and evaluate teacher characteristics with a systematic approach for effective education. As it was determined in the studies in the literature, it is necessary to examine the roles of teacher characteristics in education in a holistic framework because each teacher characteristic has a role on the effectiveness of education; therefore, the role of each teacher characteristic in educational effectiveness will probably be at different levels. This shows that the role of each teacher characteristic in education can be of relative importance. Therefore, analyzing each teacher characteristic independently of other teacher characteristics may lead to an incomplete assessment. The use of a holistic approach is required to determine the effect of teacher characteristics on education. Another issue that needs to be considered in this analysis process is to consider the relationship between teacher characteristics and cognitive, affective and psychomotor learning domains because learning domains are important in terms of targeted outcomes in an educational process (Gömleksiz and Kan, 2012). In the education process, the learning domains in the education given to the students differ according to the targeted outcomes. Therefore, the relative weight or importance of teacher characteristics in relation to learning domains should be taken into consideration in this research process because the relationship between teacher characteristics and cognitive, affective and psychomotor learning domains may not be the same. On the other hand, determining the level of functionality of teacher characteristics in practice is another problem that needs to be analyzed. Determining this situation and making an assessment will be able to answer to what extent the characteristics of teachers are functional in the effectiveness of the education given. Thus, it will be possible to evaluate the effectiveness of the education given in the context of teacher characteristics. However, such a study requires a framework based on teacher characteristics. In the literature, there was no study that included the subjects in the context mentioned in this study. However, in the literature review, there were no studies aimed at evaluating chemistry education within the context of teacher characteristics.

The main goal of this study is to analyze the characteristics of chemistry teachers and to try to propose a multi-criteria model for evaluating teachers in the context of chemistry teacher characteristics. One of the sub-goals is to determine the priorities of teacher characteristics in the effectiveness of chemistry education. The second sub-goal is to determine the level of competence of the chemistry teacher assessed on the basis of each characteristic.

\title{
2. Method
}

The method of this study was designed according to the assumptions of Analytical Hierarchy Process (AHP) and TOPSIS multi-criteria decision making techniques. The scope of the study was 9th grade chemistry course. The analysis unit of the study is a chemistry teacher teaching $9^{\text {th }}$ graders. The data of the study was provided in three ways according to the purpose of the research and the assumptions of the analysis techniques used: The first one is the binary comparison of the learning domains according to the opinion of the expert group formed in the study. The expert group consists of the instructor of the course, an experienced chemistry teacher and the author of the study. The provision of the second data was again, based on the opinion of the expert group, for the data needed for the ranking of teacher characteristics by TOPSIS technique. The third piece of data of the study was obtained from the responses given to the questionnaire consisting of 22 items (Childs, 2009) by the self-assessment approach of the 9th grade chemistry teacher himself (Table 5). The items of the questionnaire used to provide the data in the study were taken from a study which was conducted in order to improve chemistry education in the literature (Childs, 2009). In the literature, the characteristics of good teachers were classified under three dimensions. These dimensions are attitudes towards students, personal qualifications of teachers and teaching skills and practices of good teachers. The items of the survey are as follows:

\section{Attitudes towards Students}

$\checkmark$ Teachers' desire for students to learn and have full knowledge of course contents

$\checkmark$ Teachers' desire for students to improve critical thinking skills

$\checkmark$ Teacher empathy

$\checkmark$ Encouraging student feedback

$\checkmark$ Accessibility to teachers outside the classroom

\section{Personal Qualifications of Teachers}

\author{
$\checkmark$ Being willing \\ $\checkmark$ Being sincere and easy-going \\ $\checkmark$ Being motivating \\ $\checkmark$ Being qualified
}

Teaching Skills and Practices of Good Teachers 
$\checkmark \quad$ Making clear explanations

$\checkmark$ Good use of anecdotes and examples

$\checkmark \quad$ Use of simple language

$\checkmark$ Encouraging student participation

$\checkmark \quad$ Using various types of media

$\checkmark \quad$ Well-prepared and well-organized lessons

$\checkmark$ Respecting student views

$\checkmark \quad$ Avoiding being a wise guy

$\checkmark \quad$ Distribution of course notes

$\checkmark$ Having course-related materials

$\checkmark$ Considering students' previous knowledge

$\checkmark$ Appropriate and immediate feedback for student work

$\checkmark \quad$ Fun and rewarding activities for student participation

Analytical Hierarchy Process and TOPSIS techniques were used in this study to improve chemistry education within the framework of teacher characteristics. AHP structure is used to solve hierarchical and multidimensional problems. In AHP, a model representing the structure of the problem should be established first. Therefore, the elements constituting the problem of the research are determined first. In the model, the elements of the problem are indicated in a hierarchical manner (Saaty, 1990). After the model is created in AHP, a series of operations are performed for analysis. First of all, binary comparison matrices are formed by considering the levels and groups in which the elements in the AHP model take place. The comparison of the i criterion and j criterion in AHP is indicated by aij. On the contrary, the comparison of $\mathrm{j}$ criterion with $\mathrm{i}$ criterion shows the term aji. There is a reverse relationship between the components. Another AHP feature is aij $\neq 0$ ' (Vashishtha and Ramachandran, 2006). Binary comparisons in AHP are made with the scale (Table 1) improved by Saaty (1980) (Yüksel and Geban, 2018).

Table 1. Importance Levels in Binary Comparisons

\begin{tabular}{lll}
\hline $\mathbf{a}_{\mathbf{i j}}$ & Definition & Explanation \\
\hline 1 & Equal importance & Two activities contribute equally to the objective \\
\hline 3 & Weak importance & An activity is favored very slightly over another \\
\hline 5 & Strong importance & An activity is favored strongly over another \\
\hline 7 & $\begin{array}{l}\text { Very strong or } \\
\text { demonstrated } \\
\text { importance }\end{array}$ & An activity is favored very strongly over another \\
\hline $2,4,6,8$ & Extreme importance & $\begin{array}{l}\text { The evidence favoring one activity over another is of the } \\
\text { highest possible order of affirmation }\end{array}$ \\
\hline
\end{tabular}

In AHP, the matrices determined as a result of binary comparisons of the elements contained in the model are square (nxn) matrices. In each binary comparison matrix, a size-dependent comparison is performed. The weight of one element of the binary comparison matrix is calculated by the equation $\left(A-\lambda_{\max } \mathrm{I}\right) \mathrm{W}=0$. In the equation, "A" refers to matrix and "W" refers to eigenvector. " $\lambda_{\max }$ " term, on the other hand, represents "A"s eigenvalue (Chou, Lee and Chung, 2004). Another feature of AHP is the ability to calculate the consistency of comparisons. This feature predicts that the comparisons will be consistent. Consistency is based on the logical consistency of comparisons. For this, inconsistency levels of matrices are calculated. To do this, consistency index (C.I) is calculated first. The consistency index is obtained by the equation $\left(\lambda_{\max }-n\right) /(n-1)$. In this equation, " $n$ " refers to the dimension of binary comparison matrix. Following the calculation of consistency index, the inconsistency ratio (IR) is obtained by (C.I) / (R.I) (Ananda and Herath, 2003; Herath, 2004; Saaty, 1977). The random index (R.I) value in the equation differs according to the size of the binary comparison matrix. If the calculated inconsistency value is less than 0.10, it means that significant comparisons are made. (Cheng and Li 2007; Saaty 1994). Otherwise, as there is inconsistency in binary comparisons, binary comparisons are performed again. When the elements $(n)$ of the comparison matrices are large $(n \geq 5)$, the calculations are performed with the Expert Choice (2000) decision-making program. 
TOPSIS is another multi-criteria decision-making technique used in this study to improve chemistry education within the framework of teacher characteristics. (Technique for Order Performance by Similarity to İdeal Solution). The TOPSIS technique includes a large number of elements in its structure and also features ratings based on multiple criteria. TOPSIS was improved by Hwang and Yoon (1981). In the literature review, it was seen that TOPSIS technique was used in the analysis of many and various multi-criteria problems. (Dağdeviren, Yavuz and Kılınç, 2009; Ersöz, Kabak and Y1lmaz, 2011; Zyoud and Fuchs-Hanusch, 2017). Shyur (2006) explained the primary steps of TOPSIS technique as follows:

Step 1: Form the decision matrix for order. The structure of the decision matrix is illustrated as below.

$$
\begin{aligned}
& \begin{array}{llllll}
F_{1} & F_{2} & \cdots & F_{j} & \cdots & F_{n}
\end{array}
\end{aligned}
$$

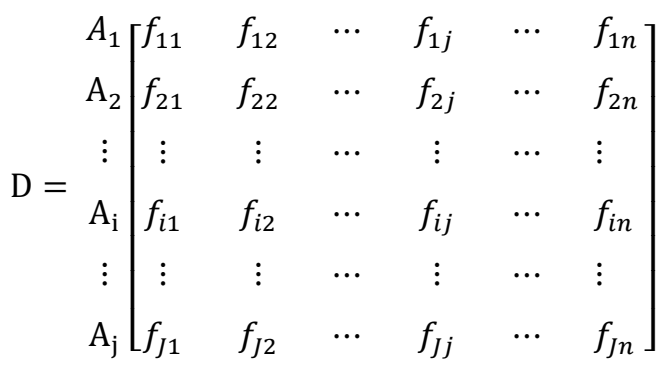

$A_{j}$ shows the potential alternatives; $i=1, \ldots m ; F i$ indicates the related $i$. characteristic or criterion, and $j=1, \ldots, n ; f_{i j}$ is a value on condition that each alternative is compared to $\mathrm{Ai}$ and each $\mathrm{Fj}$ criterion.

Step 2: Calculate the standardized decision matrix $R\left(=\left[r_{i j}\right]\right)$. The normalized value $r_{i j}$ is calculated by the following equation: $\quad r_{i j}=\frac{f_{i j}}{\sqrt{\sum_{j=1}^{n} f_{i j}^{2}}}, j=1, \ldots, n ; \quad i=1, \ldots, m$.

Step 3: Calculate the weighted normalized decision matrix which is calculated by the multiplication of normalized decision matrix and the related weights. Weighted normalized values $v_{i j}$ are calculated as follows: the $v_{i j}=w_{j} r_{i j}$, $j=1, \ldots, n ; i=1, \ldots, m, w_{j}$ statement indicates the weight of $\mathrm{j}$. characteristic or criterion.

Step 4. Identify the ideal and negative ideal solutions. $J$ indicates benefit criterion and $J$ cost criterion, it follows as:

$$
\begin{aligned}
& V^{+}=\left\{v_{1}^{+}, \ldots, v_{n}^{+}\right\}=\left\{\left(\max _{i} v_{i j} \mid j \in J\right),\left(\min _{i} v_{i j} \mid j \in J^{\prime}\right)\right\} \\
& V^{-}=\left\{v_{1}^{-}, \ldots, v_{n}^{-}\right\}=\left\{\left(\min _{i} v_{i j} \mid j \in J\right),\left(\max _{i} v_{i j} \mid j \in J^{\prime}\right)\right\},
\end{aligned}
$$

Step 5. Calculate split measurements. This is calculated using m-dimensioned Euclidean distance. Splitting each alternative from the ideal solution $\left(D_{i}^{+}\right)$is as follows:

$D_{i}^{+}=\sqrt{\sum_{j=1}^{n}\left(v_{i j}-v_{j}^{+}\right)^{2}}, i=1, \ldots, m$, likewise splitting each alternative from the negative ideal solution $\left(D_{i}^{-}\right)$is as

follows:

$$
D_{i}^{-}=\sqrt{\sum_{j=1}^{n}\left(v_{i j}-v_{j}^{-}\right)^{2}}, i=1, \ldots, m
$$

Step 6: Calculate the relative distance to the ideal solution and identify the order of choices. 
The following equation demonstrates how the calculation and ordering are done: $C_{i}=\frac{D_{i}^{-}}{D_{i}^{+}+D_{i}^{-}}, i=1, \ldots, m$. $C_{i}$ index value gets a value between 0 and 1. Large index values show better performance alternatives.

\section{Findings}

In the study, the weights of the learning domains were taken as a criterion in calculating the importance of teacher characteristics. For this reason, the weights of learning domains in relation to teacher characteristics in chemistry education were primarily determined according to expert opinion. Analytical hierarchy process was used to determine the weights of learning domains. In order to determine the weights of learning domains, paired comparisons were made according to the opinion of the expert group. The expert group was addressed the following questions in binary comparisons: How important is the cognitive domain compared to the psychomotor and affective domain in the assessment of chemistry teacher characteristics? How important is the psychomotor domain compared to the affective domain? The expert group answered these questions according to the scale in Table 1. The comparison matrix prepared accordingly is given in Table 2. The data of the comparison matrix were transferred to the Expert Choice (2000) program and the weights were determined. According to the findings of this study, cognitive learning area has the highest weight. In the second and third place, the affective learning area follows the dynamic learning domain. The consistency ratio of the matrix (0.08) showed that comparisons were made significantly.

Table 2. The Weights of Learning Domains

\begin{tabular}{lccccc}
\hline Learning Domains & Cognitive & Psychomotor & Affective & Local Weights \\
\hline Cognitive & 1 & 2 & 3 & 0.540 \\
\hline Psychomotor & $1 / 2$ & 1 & 2 & 0.297 \\
\hline Affective & $1 / 3$ & $1 / 2$ & 1 & 0.163
\end{tabular}

After determining the weights related to learning domains in the study, the importance and weights of teacher characteristics were calculated by TOPSIS technique. For this purpose, each teacher characteristic in this study was evaluated according to learning domains. Evaluation was made by expert group formed in the study. The question asked to the expert group for this evaluation was as follows: For instance, how important is "the ability of the teacher to be accessible outside the classroom" from a cognitive point of view? For instance, how important is "the ability of the teacher to be accessible outside the classroom" from a psychomotor point of view? For instance, how important is "the ability of the teacher to be accessible outside the classroom" from an affective point of view? The response of the expert group to these questions was done with a Likert-type five-point scale. On the five-point scale used, 1 represents low and 5 indicates high. In the study, all teacher characteristics were answered by the expert group with an evaluation between these degrees.

The results of the TOPSIS analysis are given in Table 3. In the last column of Table 3, the order of importance of each teacher characteristic is given. Accordingly, it was discovered that "teachers' desire to teach students critical thinking skills" got in the first place, with "use of simple language" in the second place, "teachers' desire for students to learn and have full knowledge of course contents" in the third order or importance, "well-prepared and well-organized lessons" in the fourth place, and "having course-related materials" in the fifth order of importance. The order of importance of other teacher characteristics is given in Table 3. In this study, besides the determination of the order of importance of teacher characteristics by TOPSIS technique, weights of chemistry teacher characteristics were also calculated. This calculation was made by standardizing Ci values in Table 3. Standardized Ci values calculated accordingly are given in the second column of Table 5 . 
Table 3. Prioritization of Teacher Characteristics According to Learning Domains

\begin{tabular}{|c|c|c|c|c|c|c|c|c|}
\hline \multirow{2}{*}{$\begin{array}{l}\text { Teacher } \\
\text { Characteristics }\end{array}$} & \multicolumn{3}{|c|}{ Learning Domains } & \multirow{2}{*}{$\begin{array}{l}\text { (Cogx0.540+ } \\
\text { Psyx0.297+ } \\
\text { Affx0.163) }\end{array}$} & \multirow[t]{2}{*}{$\mathrm{D}^{+}$} & \multirow[t]{2}{*}{$\mathbf{D}^{-}$} & \multirow[t]{2}{*}{$C_{i}$} & \multirow{2}{*}{$\begin{array}{l}\text { Order } \\
\text { Importance }\end{array}$} \\
\hline & $\begin{array}{l}\text { Cognitive } \\
0.540\end{array}$ & $\begin{array}{l}\text { Psychomotor } \\
0.297\end{array}$ & $\begin{array}{l}\text { Affective } \\
0.163\end{array}$ & & & & & \\
\hline $\begin{array}{l}\text { Teachers' desire for } \\
\text { students to learn } \\
\text { and have full } \\
\text { knowledge of } \\
\text { course contents }\end{array}$ & 5 & 5 & 3 & 4.674 & 0.0219 & 0.1010 & 0.8216 & 3 \\
\hline $\begin{array}{l}\text { Teachers' desire for } \\
\text { students to improve } \\
\text { critical thinking } \\
\text { skills }\end{array}$ & 5 & 5 & 4 & 4.837 & 0.0110 & 0.1027 & 0.9036 & 1 \\
\hline Teacher empathy & 3 & 5 & 4 & 3.757 & 0.0667 & 0.0437 & 0.3959 & 16 \\
\hline $\begin{array}{l}\text { Encouraging } \\
\text { student feedback }\end{array}$ & 3 & 5 & 4 & 3.757 & 0.0667 & 0.0437 & 0.3959 & 17 \\
\hline $\begin{array}{l}\text { Accessibility to } \\
\text { teachers outside the } \\
\text { classroom }\end{array}$ & 3 & 5 & 2 & 3.431 & 0.0758 & 0.0329 & 0.3024 & 20 \\
\hline Being willing & 3 & 3 & 4 & 3.163 & 0.0667 & 0.0437 & 0.3959 & 18 \\
\hline $\begin{array}{l}\text { Being sincere and } \\
\text { easygoing }\end{array}$ & 3 & 5 & 5 & 3.920 & 0.0658 & 0.0501 & 0.4324 & 12 \\
\hline Being motivating & 3 & 5 & 4 & 3.757 & 0.0667 & 0.0437 & 0.3959 & 19 \\
\hline $\begin{array}{l}\text { Teachers with a } \\
\text { good sense of } \\
\text { humor }\end{array}$ & 3 & 5 & 5 & 3.920 & 0.0658 & 0.0501 & 0.4324 & 13 \\
\hline $\begin{array}{ll}\text { Making } & \text { clear } \\
\text { explanations } & \\
\end{array}$ & 5 & 5 & 3 & 4.674 & 0.0288 & 0.0992 & 0.7753 & 6 \\
\hline $\begin{array}{lr}\text { Good use } & \text { of } \\
\text { anecdotes } & \text { and } \\
\text { examples } & \\
\end{array}$ & 5 & 3 & 3 & 4.080 & 0.0288 & 0.0992 & 0.7753 & 7 \\
\hline $\begin{array}{l}\text { Use of simple } \\
\text { language }\end{array}$ & 5 & 3 & 4 & 4.243 & 0.0216 & 0.1010 & 0.8238 & 2 \\
\hline $\begin{array}{l}\text { Encouraging } \\
\text { student } \\
\text { participation }\end{array}$ & 3 & 3 & 5 & 3.326 & 0.0658 & 0.0501 & 0.4324 & 14 \\
\hline $\begin{array}{l}\text { Using various types } \\
\text { of media }\end{array}$ & 3 & 5 & 2 & 3.431 & 0.0758 & 0.0329 & 0.3024 & 21 \\
\hline $\begin{array}{l}\text { Well-prepared and } \\
\text { well-organized } \\
\text { lessons }\end{array}$ & 5 & 3 & 3 & 4.080 & 0.0219 & 0.1010 & 0.8216 & 4 \\
\hline $\begin{array}{l}\text { Respecting student } \\
\text { views }\end{array}$ & 4 & 5 & 5 & 4.460 & 0.0329 & 0.0758 & 0.6976 & 8 \\
\hline $\begin{array}{l}\text { Avoiding being a } \\
\text { wise guy }\end{array}$ & 2 & 5 & 3 & 3.054 & 0.1015 & 0.0144 & 0.1241 & 22 \\
\hline $\begin{array}{ll}\begin{array}{l}\text { Distribution } \\
\text { course notes }\end{array} & \text { of } \\
\end{array}$ & 4 & 4 & 4 & 4.000 & 0.0347 & 0.0718 & 0.6744 & 10 \\
\hline $\begin{array}{l}\text { Having } \\
\text { course-related } \\
\text { materials } \\
\end{array}$ & 5 & 5 & 3 & 4.674 & 0.0219 & 0.1010 & 0.8216 & 5 \\
\hline $\begin{array}{l}\text { Considering } \\
\text { students' previous } \\
\text { knowledge }\end{array}$ & 4 & 5 & 3 & 4.134 & 0.0395 & 0.0692 & 0.6366 & 11 \\
\hline $\begin{array}{l}\text { Appropriate and } \\
\text { immediate feedback } \\
\text { for student work }\end{array}$ & 4 & 5 & 5 & 4.460 & 0.0329 & 0.0758 & 0.6976 & 9 \\
\hline $\begin{array}{l}\text { Fun and rewarding } \\
\text { activities for } \\
\text { student } \\
\text { participation }\end{array}$ & 3 & 5 & 5 & 3.920 & 0.0658 & 0.0501 & 0.4324 & 15 \\
\hline
\end{tabular}


At this stage of the study, the chemistry teacher was evaluated in terms of teacher characteristics. In the study, the assessment was made by the self-assessment approach of the 9th grade chemistry course by the teacher himself and the answers given to a 22-item questionnaire (Childs, 2009). The answers of the teachers within the scope of the study were made with the scale given in Table 4 (Yüksel and Dağdeviren 2006). The evaluation question was: For instance, "at what level is teachers' desire for students to learn and have full knowledge of course contents?" The answer to this question was answered with one of the competence levels given in Table 4. For example, the answer to this question is very good and the corresponding value is 1.0.

Table 4. Teacher Characteristics Evaluation Scale

\begin{tabular}{lc}
\hline Competence Level & Value \\
\hline Very high (VH) & 1.0 \\
\hline High (H) & 0.8 \\
\hline Intermediate (I) & 0.6 \\
\hline Low (L) & 0.4 \\
\hline Very Low (VL) & 0.2 \\
\hline Not Applicable (NA) & 0.0 \\
\hline
\end{tabular}

In Table 5, the responses to the evaluation of teacher characteristics were provided in the third column, with statistical values in the fourth and the calculated values of the evaluation of the teacher in this study in relation to teacher characteristics in the fifth column. The level of characteristic in the last column of Table 5 was obtained through the multiplication of standardized values $\left(\mathrm{C}_{\mathrm{i}}\right)$ and competence values $(\mathrm{PV})$.

Table 5. Evaluation of the Chemistry Teacher in the Context of Teacher Characteristics

\begin{tabular}{|c|c|c|c|c|}
\hline Characteristics of Chemistry Teachers & $\begin{array}{l}\text { Standardized Values } \\
\left(\mathbf{C}_{\mathrm{i}}\right)\end{array}$ & $\begin{array}{l}\text { Competence } \\
\text { Level } \\
(\mathrm{PV}) \\
\end{array}$ & $\begin{array}{l}\text { Scale } \\
\text { Value } \\
\text { (Table 5) } \\
\end{array}$ & $\begin{array}{l}\text { Characteristic } \\
\text { Level } \\
\left(C_{\mathrm{i}}\right) \mathrm{X}(\mathrm{PV}) \\
\end{array}$ \\
\hline $\begin{array}{l}\text { Teachers' desire for students to learn and have full knowledge } \\
\text { of course contents }\end{array}$ & 0.0658 & $\mathrm{VH}$ & 1.00 & 0.0658 \\
\hline Teachers' desire for students to improve critical thinking skills & 0.0723 & VH & 1.00 & 0.0723 \\
\hline Teacher empathy & 0.0317 & $\mathrm{H}$ & 0.80 & 0.0254 \\
\hline Encouraging student feedback & 0.0317 & $\mathrm{H}$ & 0.80 & 0.0254 \\
\hline Accessibility to teachers outside the classroom & 0.0242 & I & 0.60 & 0.0145 \\
\hline Being willing & 0.0317 & $\mathrm{H}$ & 0.80 & 0.0254 \\
\hline Being sincere and easygoing & 0.0346 & $\mathrm{H}$ & 0.80 & 0.0277 \\
\hline Being motivating & 0.0317 & $\mathrm{H}$ & 0.80 & 0.0254 \\
\hline Teachers with a good sense of humor & 0.0346 & $\mathrm{H}$ & 0.80 & 0.0277 \\
\hline Making clear explanations & 0.0621 & $\mathrm{H}$ & 0.80 & 0.0497 \\
\hline Good use of anecdotes and examples & 0.0621 & $\mathrm{H}$ & 0.80 & 0.0497 \\
\hline Using simple language & 0.0659 & $\mathrm{H}$ & 0.80 & 0.0528 \\
\hline Encouraging student participation & 0.0346 & $\mathrm{H}$ & 0.80 & 0.0277 \\
\hline Using various types of media & 0.0242 & I & 0.60 & 0.0145 \\
\hline Well-prepared and well-organized lessons & 0.0658 & $\mathrm{VH}$ & 1.00 & 0.0658 \\
\hline Respecting student views & 0.0558 & $\mathrm{H}$ & 0.80 & 0.0447 \\
\hline Avoiding being a wise guy & 0.0099 & $\mathrm{VH}$ & 1.00 & 0.0099 \\
\hline Distribution of course notes & 0.0540 & $\mathrm{H}$ & 0.80 & 0.0432 \\
\hline Having course-related materials & 0.0658 & $\mathrm{H}$ & 0.80 & 0.0526 \\
\hline Considering students' previous knowledge & 0.0510 & VH & 1.00 & 0.0510 \\
\hline Appropriate and immediate feedback for student work & 0.0558 & VH & 1.00 & 0.0558 \\
\hline Fun and rewarding activities for student participation & 0.0346 & VH & 1.00 & 0.0346 \\
\hline Total & & Total Level & & 0.8614 \\
\hline
\end{tabular}

Table 6 presents data on the detailed analysis and evaluation of teacher characteristics. In the second column of Table 6 , the general weight of each teacher characteristic was given, and in the third column, the level of adequacy of each 
teacher characteristic was evaluated and the deviation values were given in the fourth column. The deviation is the difference between the overall weight value and the competence level of the teacher assessed for the characteristic. No deviations were found in this study in the following teacher characteristics: "Teachers' desire for students to learn and have full knowledge of course contents", "Teachers' desire for students to improve critical thinking skills", "well-prepared and well-organized lessons", "avoiding being a wise guy", "considering students' previous knowledge", "appropriate and immediate feedback for student work", and "Fun and rewarding activities for student participation". There seems to be a 0,138634 deviation in the total of the other characteristics.

Table 6. Detailed Evaluation of Teacher Characteristics

\begin{tabular}{lccc}
\hline Characteristics of Chemistry Teachers & $\begin{array}{c}\text { Standardized } \\
\text { Values } \\
\left(\mathbf{C}_{\mathbf{i}}\right)\end{array}$ & $\begin{array}{c}\text { Evaluated Teacher's } \\
\text { characteristic level (Ev) })\end{array}$ & $\begin{array}{c}\text { Deviation } \\
\left(\mathbf{C}_{\mathbf{i}}\right) \mathbf{(}(\mathbf{E v})\end{array}$ \\
\hline $\begin{array}{l}\text { Teachers' desire for students to learn and have full } \\
\text { knowledge of course contents }\end{array}$ & 0.0658 & 0.0658 & 0.0000 \\
\hline $\begin{array}{l}\text { Teachers' desire for students to improve critical } \\
\text { thinking skills }\end{array}$ & 0.0723 & 0.0723 & 0.0000 \\
\hline Teacher empathy & 0.0317 & 0.0254 & 0.0063 \\
\hline Encouraging student feedback & 0.0317 & 0.0254 & 0.0063 \\
\hline Accessibility to teachers outside the classroom & 0.0242 & 0.0145 & 0.0097 \\
\hline Being willing & 0.0317 & 0.0254 & 0.0063 \\
\hline Being sincere and easygoing & 0.0346 & 0.0277 & 0.0069 \\
\hline Being motivating & 0.0317 & 0.0254 & 0.0063 \\
\hline Teachers with a good sense of humor & 0.0346 & 0.0277 & 0.0069 \\
\hline Making clear explanations & 0.0621 & 0.0497 & 0.0124 \\
\hline Good use of anecdotes and examples & 0.0621 & 0.0497 & 0.0124 \\
\hline Using simple language & 0.0660 & 0.0528 & 0.0132 \\
\hline Encouraging student participation & 0.0346 & 0.0277 & 0.0069 \\
\hline Using various types of media & 0.0242 & 0.0145 & 0.0097 \\
\hline Well-prepared and well-organized lessons & 0.0658 & 0.0658 & 0.0000 \\
\hline Respecting student views & 0.0558 & 0.0447 & 0.0112 \\
\hline Avoiding being a wise guy & 0.0099 & 0.0099 & 0.0000 \\
\hline Distribution of course notes & 0.0540 & 0.0432 & 0.0108 \\
\hline Having course-related materials & 0.0658 & 0.0526 & 0.0132 \\
\hline Considering students' previous knowledge & 0.0510 & 0.0510 & 0.0000 \\
\hline $\begin{array}{l}\text { Appropriate and immediate feedback for student } \\
\text { work }\end{array}$ & 0.0558 & 0.0558 & 0.0000 \\
\hline $\begin{array}{l}\text { Fun and rewarding activities for student } \\
\text { participation }\end{array}$ & 0.0346 & 0.0346 & 0.0000 \\
\hline Total & 1.0000 & 0.8614 & 0.1386 \\
\hline 4. Discussion \& Cont & &
\end{tabular}

\section{Discussion \& Conclusion}

In this study, a multi-criteria model was proposed to analyze the characteristics of chemistry teachers and evaluate the competence of teachers in the context of characteristics of chemistry teachers. The AHP and TOPSIS techniques used in the proposed model provide a holistic approach to the aim of the study and allow the detailed evaluation of the results. Besides the functionality of the methodological results of the study, it was also possible to analyze and evaluate the teacher characteristics, which was one of the main arguments of the study in the context of learning domains. According to AHP results, when the learning domains were evaluated in terms of weights, the cognitive learning domain had the highest weight. The psychomotor learning domain was in the second place, with affective learning domain in the third place. These results showed that cognitive learning domain was more important than the other two domains in the evaluation of teacher characteristics whereas psychomotor and affective learning domains were two important components in the evaluation of teacher characteristics. This result of the study stated that teacher characteristics should not be considered and evaluated in the context of only one component. Although the characteristics of a teacher require a cognitive-weighted behavior and attitude, it can be said that it is important that teachers have characteristics that take into account the psychomotor and affective learning domains.

With the model proposed in the study, the importance of teacher characteristics and the analysis of teacher characteristics in the context of learning domains were calculated by TOPSIS method. According to the results of 
TOPSIS analysis, it was found that "teacher's desire to improve students' critical thinking skills" was the first among the characteristics consisting of 22 items. The four characteristics followed subsequently were "use of simple language", "teachers' desire for learners to learn and have full knowledge of course content", "well-prepared and well-organized lessons", and "having course-related materials". The total weight of the teacher characteristics identified during the first five significance values calculated as a result of standardizing the order of importance of TOPSIS analysis was 0,336 . The weight of teacher characteristics in the first five order of importance had an important share in the other 17 items. Therefore, it can be said that these five characteristics have a distinctive role in the assessment of the characteristics of chemistry teachers. In practice, teachers or administrators will be able to make it easier for them to achieve an effective result in education by taking these five characteristics into consideration and as a result of their work towards these five characteristics.

In the study, it was determined that the role of each teacher's characteristics in the given chemistry education was determined as well as the degree of competency of the teacher providing chemistry education according to the characteristics of the teachers. According to the results of this study, the teacher in this study was found to be very high in terms of competence levels in relation to the following characteristics: "teachers' desire for students to learn and have full knowledge of course content", "teachers' desire to improve students' critical thinking skills", "well-prepared and well-organized lessons", "avoiding being a wise guy", "considering students' previous knowledge", "appropriate and immediate feedback for student work", and "fun and rewarding activities for student participation". In other words, the teacher was not found to be incompetent in terms of these characteristics. Despite deviations in other characteristics, the total deviation was 0.11386 . On the other hand, according to all teacher characteristics, the total competence level of the teacher in the study was 0.8614 . It can be said that the teacher, who has this level of qualification, has an adequate teaching quality.

The findings of this study are limited to the characteristics of the chemistry teacher in the context of this research. The findings obtained from another chemistry teacher may yield differences. For this reason, it is not possible to generalize the results for all chemistry teachers. Also, further research can be conducted on a number of subjects. The first research could be carried out on the development of discriminant analysis and regression analysis models predicting teacher competence of the teacher characteristics in the first five orders of importance with their determined weights. Another research can be conducted on the development of discriminant analysis and regression analysis predicting the success of chemistry course or school based on teacher characteristics.

\section{References}

Ananda, J., \& Herath, G. (2003). The use of Analytic Hierarchy Process to incorporate stakeholder preferences into regional forest planning. Forest Policy and Economics, 5, 13-26. https://doi.org/10.1016/S1389-9341(02)00043-6

Arsal, Z. (2004). Ülkemizi 21. yüzyıla hazırlayacak ve kalkındıracak öğretmen tipinin özellikleri. Abant İzzet Baysal Üniversitesi Eğitim Fakültesi Dergisi, 4(7), 99-116.

Batı, K. (2018). Türkiye'de Fen Eğitimi Ve Kimya Eğitimi Laboratuvar Uygulamalarına Genel Bir Bakış. Doğu Anadolu Sosyal Bilimlerde Eğilimler Dergisi, 2(1), 45-55.

Çalık, M., Ayas, A., \& Ünal, S. (2006). Çözünme Kavramıyla İlgili Öğrenci Kavramalarının Tespiti: Bir Yaşlar Arası Karşılaştırma Çalışması. Türk Eğitim Bilimleri Dergisi, 4(3), 309-322.

Cheng, E. W., \& Li, H. (2007). Application of ANP in process models: An example of strategic partnering. Building and environment, 42(1), 278-287. https://doi.org/10.1016/j.buildenv.2005.07.031

Childs, P. E. (2009). Improving chemical education: turning research into effective practice. Chemistry Education Research and Practice, 10(3), 189-203. https://doi.org/10.1039/b914496j

Chou, Y., Lee, C., \& Chung, J. (2004). Understanding m-commerce payment systems through the analytic hierarchy process. Journal of Business Research, 57(12), 1423-1430. https://doi.org/10.1016/S0148-2963(02)00432-0

Coşkun, A. (2016). Din, Bilim Ve Felsefe İlişkileri. Trakya Üniversitesi Sosyal Bilimler Dergisi, 18(1), 213-229.

Dağdeviren, M., Yavuz, S., \& Kılınç, N. (2009). Weapon selection using the AHP and TOPSIS methods under fuzzy environment. Expert Systems with Applications, 36(4), 8143-8151. https://doi.org/10.1016/j.eswa.2008.10.016

Ersöz, F., Kabak, M., \& Yılmaz, Z. (2011). Lisansüstü Öğrenimde Ders Seçimine Yönelik Bir Model Önerisi. Afyon Kocatepe Üniversitesi İktisadi ve İdari Bilimler Fakültesi Dergisi, 13(2), 227-249.

Expert Choice. (2000). Expert choice. Analytical Hierarchy Process (AHP) Software, Version, 9.

Gömleksiz, M. N., \& Kan, A. Ü. (2012). Affective Dimension in Education and Affective Learning, Turkish Studies, 7(1), 1159-1177. https://doi.org/10.7827/TurkishStudies.3127 
Herath, G. (2004). Incorporating community objectives in improved wetland management: the use of the analytic hierarchy process. Journal of environmental management, 70(3), 263-273. https://doi.org/10.1016/j.jenvman.2003.12.011

Hwang, C. L., \& Yoon, K. (1981). Multiple Attribute Decision Making Methods and Applications. New York: Springer-Verlag. https://doi.org/10.1007/978-3-642-48318-9

Mete, P. (2018). A Case Study of the Problems Faced by 9th-grade The Physics-Chemistry-Biology Teachers in The Course of Science Education. Necatibey Faculty of Education Electronic Journal of Science \& Mathematics Education, 12(2), 673-697.

Özkan, M., \& Arslantaş, H. (2013). Etkili Öğretmen Özellikleri Üzerine Sıralama Yöntemiyle Bir Ölçekleme Çalışması. Trakya Üniversitesi Sosyal Bilimler Dergisi, 15(1), 311-330.

Özlem, D. (1994). Felsefe Açısından Bilim. Tarım Ekonomisi Dergisi, 2(1 ve 2), 1-6.

Saaty, T. L. (1977). A scaling method for priorities in hierarchical structures. Journal of mathematical psychology, 15(3), 234-281. https://doi.org/10.1016/0022-2496(77)90033-5

Saaty, T. L. (1980). The analytic Hierarchy Process. McGraw-Hill international. New York, NY, USA. https://doi.org/10.21236/ADA214804

Saaty, T. L. (1990). How to make a decision: the analytic hierarchy process. European journal of operational research, 48(1), 9-26. https://doi.org/10.1016/0377-2217(90)90057-I

Saaty, T. L. (1994). How to make a decision: the analytic hierarchy process. Interfaces, 24(6), 19-43. https://doi.org/10.1287/inte.24.6.19

Shyur, H. J. (2006). COTS evaluation using modified TOPSIS and ANP. Applied mathematics and computation, 177(1), 251-259. https://doi.org/10.1016/j.amc.2005.11.006

Tsaparlis, G., (2015). Problems and Solutions in Chemistry Education, Journal of the Turkish Chemical Society, 1(1), $1-30$.

Ulutaş, B., Üner, S., Turan, O. N., Yalçın, Ç. A., \& Akkuş, H. (2015). Türkiye'deki Kimya Eğitimi Makalelerinin İncelenmesi: 2000-2013. Ahi Evran Üniversitesi Krrşehir Eğitim Fakültesi Dergisi, 16(2), 141-160.

Vashishtha, S., \& Ramachandran, M. (2006). Multicriteria evaluation of demand side management (DSM) implementation strategies in the Indian power sector. Energy, 31(12), 2210-2225. https://doi.org/10.1016/j.energy.2005.10.005

Yavuz, A. (2008). Felsefeden Yoksun Bir Eğitim Olur Mu? Olursa Eğitim Ne Olur/Nasıl Olur?" Tarihsel Gelişim Sürecinde Eğitim--Felsefe--Bilim İlişsisi Üzerine Bir Analiz.". Çağdaş Eğitim Dergisi, 33, 21-32.

Yetisir, M. I. (2014). A study on school performance in terms of some teacher characteristics. Journal of Education and Future, (5), 13-24.

Yüksel, İ., \& Dağdeviren, M. (2006). Sosyo-Teknik Sistemlerde Hatalı Davranış Riskini Belirlemeye Yönelik Bir Erken Uyarı Modeli. Gazi Üniversitesi Mühendislik-Mimarlık Fakültesi Dergisi, 21(4), 791-799.

Yüksel, M., \& Geban, Ö. (2018). Student Performance Task Assessment Using Multiple Criteria Decision Making (MCDM) Techniques: An Application for 9th Grade Chemistry Course. Bartın Üniversitesi Eğitim Fakültesi Dergisi, 7(3), 874-901. https://doi.org/10.14686/buefad.400787

Zyoud, S. H., \& Fuchs-Hanusch, D. (2017). A bibliometric-based survey on AHP and TOPSIS techniques. Expert systems with applications, 78, 158-181. https://doi.org/10.1016/j.eswa.2017.02.016

\section{Copyrights}

Copyright for this article is retained by the author(s), with first publication rights granted to the journal.

This is an open-access article distributed under the terms and conditions of the Creative Commons Attribution license which permits unrestricted use, distribution, and reproduction in any medium, provided the original work is properly cited. 